\title{
Gesinsbediening in 'n postmoderne kerk: Modelle en metodes
}

\begin{tabular}{|c|c|}
\hline \multicolumn{2}{|c|}{$\begin{array}{l}\text { Author: } \\
\text { Jacobus M. (Thinus) van } \\
\text { Staden }^{1}\end{array}$} \\
\hline $\begin{array}{l}\text { Affiliation: } \\
{ }^{1} \text { Department } \\
\text { Theology, Facu } \\
\text { Theology, Univ } \\
\text { Pretoria, Soutr }\end{array}$ & $\begin{array}{l}\text { Practical } \\
\text { Ity of } \\
\text { ersity of } \\
\text { Africa }\end{array}$ \\
\hline $\begin{array}{l}\text { Note: } \\
\text { Dr Thinus van } \\
\text { a research ass } \\
\text { Prof Dr Yoland } \\
\text { at the Departn } \\
\text { Practical Theo } \\
\text { of Theology, U } \\
\text { Pretoria, Preto } \\
\text { Africa. This art } \\
\text { version of asp } \\
\text { PhD thesis of } \\
\text { Staden with Pr } \\
\text { Dreyer as pron }\end{array}$ & $\begin{array}{l}\text { Staden is } \\
\text { ociate of } \\
\text { a Dreyer } \\
\text { hent of } \\
\text { ogy, Faculty } \\
\text { niversity of } \\
\text { ria, South } \\
\text { icle is a revised } \\
\text { ects of the } \\
\text { or Thinus van } \\
\text { of. Yolanda } \\
\text { noter. }\end{array}$ \\
\hline $\begin{array}{l}\text { Corresponden } \\
\text { Thinus van Sta }\end{array}$ & $\begin{array}{l}\text { ce to: } \\
\text { den }\end{array}$ \\
\hline $\begin{array}{l}\text { Email: } \\
\text { wysmydiesone }\end{array}$ & Dgmail.com \\
\hline $\begin{array}{l}\text { Postal address } \\
\text { Private Bag X2 } \\
0028, \text { South A }\end{array}$ & $\begin{array}{l}\text { 0, Hatfield } \\
\text { rica }\end{array}$ \\
\hline $\begin{array}{l}\text { Dates: } \\
\text { Received: } 11 \mathrm{~J} \\
\text { Accepted: } 15 \\
\text { Published: } 20\end{array}$ & $\begin{array}{l}\text { Jly } 2014 \\
\text { lug. } 2014 \\
\text { Vov. } 2014\end{array}$ \\
\hline $\begin{array}{l}\text { How to cite th } \\
\text { Van Staden, J.I } \\
\text { 'Gesinsbedien } \\
\text { postmoderne } \\
\text { en metodes', } \\
\text { Studies/Theolc } \\
70(1) \text {, Art. \#27 } \\
\text { http://dx.doi. } \\
\text { hts.v70i1.2783 }\end{array}$ & $\begin{array}{l}\text { is article: } \\
\text { И., 2014, } \\
\text { ng in 'n } \\
\text { kerk: Modelle } \\
\text { ITS Teologiese } \\
\text { gical Studies } \\
83,8 \text { pages. } \\
\text { rg/10.4102/ }\end{array}$ \\
\hline $\begin{array}{l}\text { Copyright: } \\
\text { C 2014. The A } \\
\text { Licensee: AOS } \\
\text { OpenJournals. } \\
\text { is licensed und } \\
\text { Creative Comn } \\
\text { Attribution Lic }\end{array}$ & $\begin{array}{l}\text { uthors. } \\
\text { S } \\
\text { This work } \\
\text { er the } \\
\text { nons } \\
\text { ense. }\end{array}$ \\
\hline Read online: & $\begin{array}{l}\text { Scan this QR } \\
\text { code with your } \\
\text { smart phone or } \\
\text { mobile device } \\
\text { to read online. }\end{array}$ \\
\hline
\end{tabular}

Family ministry in a postmodern church. The aim of the article is to reflect on the necessity for family ministry in the church today, and to explore different models and methods for doing it. This article must be understood against the backdrop of the challenges facing mainline churches, of which the decline in numbers, the lack of support for programmes and initiatives on behalf of families, and the apparent inability to minister effectively to young people, are the most pressing. Since the early church there has been a close relationship between church and home. Not only did rituals and liturgies spill from the gathered congregation into homes; metaphors from family life also provided images and language to the early church. In the last few decades there has been a rekindled interest in the home as the primary incubator for faith formation. Several books, articles, organisations, programs, consultants and churches have described their approach as 'family ministry'. From a practical-theological viewpoint, there must be a set of criteria by which these approaches could be evaluated. This article aims to contribute in this regard, and to critique different approaches to family ministry.

\section{Inleiding}

Wanneer gesinne $e^{1}$ ter sprake kom binne die raamwerk van gemeentelike bediening, bestaan die risiko dat persone wat nie aan gesinne behoort nie, of deel is van gesinne wat nie ooreenstem met tradisionele gesinsvorme nie, verwond en verkleineer word (kyk Browning 2007:56; Müller 2002:13; Reuther 2001:212). Daar is 'n poging om hierdie struikelblok te oorkom deur eerder van familiebediening te praat. Dit is waarskynlik 'n meer aanvaarbare vertaling van die Engelse begrip 'Family Ministry', maar familie verwys primêr na persone wat bloedverwante is (vgl. Odendal \& Gouws 2005:229). In hierdie opsig is die woord gesin meer inklusief, aangesien dit verwys na verwante sowel as 'nie-verwante persone tussen wie daar 'n innige, vertroulike verhouding bestaan' (Odendal \& Gouws 2005:229). 'n Literêre ondersoek laat die ondersoeker haas besef dat hierdie bloot ' $n$ kosmetiese aangeleentheid is, aangesien daar onderliggend aan hierdie begrippe dieper hermeneutiese probleme opgesluit lê (kyk Van Eck 2007:125-126). Watter woordkeuse ook al gemaak word, gesin en familie word soms as uitsluitende begrippe verstaan en aangewend. Dit gaan nie alleen oor die vraag of gemeentes alle gesinne onvoorwaardelik aanvaar nie, maar of die kerk alle gesinsvorme bevorder. Garland (1999:21) skryf in hierdie verband: 'It seems obvious that no agreement will be reached on what families need if there is conflict over what a family is'.

Müller (2002:13) wil wegbeweeg van 'n normatiewe gesinsvorm en eerder fokus op normatiewe gesinsfunksies. Vanuit 'n eko-feministiese perspektief stel Reuther (2001:207-209) voor dat alle gesinsvorme sonder enige vooroordeel aanvaar en bevorder behoort te word, naamlik enkelouers, gay en lesbiese pare, aanneemgesinne, gesinne waar kinders verwek is deur in-vitro-behandeling, dubbele-inkomste heteroseksuele pare, die drie- of viergenerasiefamilie, saamgestelde gesinne en saamwoonpare. Olson en Leonard (1996:25-26), wat 'n empiriese definisie eerder as 'n ideologiese een verkies om die gesin te beskryf, is dit met Reuther eens.

Browning $(2007,2003)$ en Thatcher (1999) staan'n onkritiese aanvaarding van gesinspluralisme teë. Aan die een kant word die posisie verwerp dat alle meesternarratiewe uit die Christelike verlede afbrekend is (Thatcher 1999:54-61, 290-291). Wanneer tekste van die Ou en Nuwe Testament, asook dié van teoloë soos Aquinas en Luther, benader word vanuit 'n bepaalde hermeneutiese lens, naamlik 'n trajek van gelyke agting (kyk Browning 2003:43), word belangrike teologiese tradisies behou wat heilsaam inwerk op die ontwikkeling van 'n hedendaagse liefdesetiek van gelyke agting. Aan die ander kant word die magsmisbruik en vergrype wat gepaard gaan met 'n plastiese seksualiteit, pragmatiese seksuele etiek en 'n sekulêre godsdiens van romantiese liefde wat kenmerkend is van 'n post-Christelike etiek oorgesien, aldus Thatcher (1999:54-61, 290-291).

1.In Afrikaans kan die begrippe gesin en familie as wisselterme voorkom. Hier word die keuse gemaak om voorkeur te verleen aan die begrip gesin, aangesien dit beide na biologies verwante persone kan verwys sowel as' $n$ groep 'nie-verwante persone tussen wie daar 'n innige, vertroulike verhouding bestaan' (Odendal \& Gouws 2005:292). Die begrip familie verwys primêr na bloedverwante persone (vgl. Odendal \& Gouws 2005:229). 
Die individualistiese, voorlopige en hersienbare aard van verhoudings bied nie beter vooruitsigte vir mans, vroue en veral kinders ${ }^{2}$ nie.

In 'n vorige artikel het Van Staden en Dreyer (2013) beredeneer dat die begrippe 'huwelik' en 'gesin' herwin behoort te word binne 'n postmoderne paradigma, weg van 'n patriargale en sakramentele verstaan, nader aan 'n verbondsmatige ruimte waar die spirituele dimensie van die huwelik en gesin beklemtoon word. Dus bied 'n analogiese en dialogiese werkswyse (kyk Browning 2003, 2007) die moontlikheid dat sentrale temas uit die Christelike tradisie herwin kan word, terwyl enige vorm van patriargie teengestaan word. 'n Hermeneutiek van suspisie in die praktiese teologie dra by tot die bewuswording dat die Christelike tradisie 'n dinamiese proses is wat onderhandeling insluit en ruimte maak daarvoor dat wat soms as 'Godgegewe' aangebied word, in werklikheid sosiale konstrukte met onderliggende magsbelange kan wees. Dit beteken egter nie dat 'n teologie van die skepping en alle teologiese tradisies summier verwerp word nie. Daar word krities en suspisieus ten opsigte van mag daarmee in gesprek getree met die oog daarop om sentrale temas te identifiseer ter verryking van die Christelike geloofspraktyk vandag.

'n Nuwe orde en huishouding word bepleit wat geskoei is op Jesus se benadering tot die huwelik, familie en gemeenskap, waarin hiërargie en status vervang word met 'n nuwe gemeenskap van gelykheid (vgl. Browning 2007:44-45; Browning et al. 2000:134-149; Bells 1998:201-203; Carter 1998:224-228; Osiek \& Balch 1997:136-139). Sonder om sakramentele status daaraan te verleen, behoort die huwelik belangrik geag te word omdat dit as instelling vir baie eeue reeds ' $n$ bousteen is vir gesinne, gemeentes en gemeenskappe (Van Staden \& Dreyer 2013:4). 'n Gesinsetiek wat as basisteorie kan dien vir die ontwikkeling van toepaslike gesinsbedieningspraktyke, onderskryf die huwelik as 'n niehiërargiese, post-partriargale, lewenslange verbond tussen twee persone, geskoei op ' $n$ etiek van gelyke agting en self-opoffering. Dit is die primêre ruimte waar 'n huwelik- en gesinsspiritualiteit beoefen word, waar kinders in verantwoordelikheid voor God opgevoed word, en albei ouers betrokke is by die versorging en onderrig van hul kinders.

'n Nuwe orde en huishouding kan vertroostend en rigtinggewend wees vir alle gesinne, wat die gesinsvorm ook al mag wees - of daar egskeiding plaasgevind het en of dit hersaamgestelde gesinne is. Die Bybel getuig van 'n voortdurende spanning tussen ideaal en werklikheid, ook met betrekking tot die familie. Die huwelik behoort ook nie verstaan te word as normatiewe lewenstaat nie, soos gesien is in die orde vir weduwees binne die vroeë kerk (vgl. Seim 1998:230-231). Vir enkellopendes wat die keuse maak om nie

2.Daar is teoloë en sielkundiges wat meen dat kinders uit huisgesinne waar beide ouers teenwoordig is, beter daaraan toe is as kinders uit enkelouergesinne en ouers teenwoordig is, beter daaraan toe is as kinders uit enkelouergesinne en
hersaamgestelde gesinne (kyk Browning 2007:57-58; Gottman 1999:3-4; Thatcher 1999:142-146). te trou nie, geld 'n gesinspiritualiteit nét soveel as vir persone wat in die huwelik tree. Toepaslike gesinsbedieningsmodelle en -metodes behoort vanaf hierdie basis ontwikkel te word. Daartoe wou hierdie artikel 'n bydrae lewer.

\section{Gesinsbediening}

Kerke is uniek geposisioneer om 'n positiewe en opbouende invloed uit te oefen op die geestelike en emosionele welstand van gesinne. Die geestelike en emosionele welstand van gesinne is nie alleen voordelig vir ouers, kinders en gemeenskappe nie, maar ook vir gemeentes (Van Staden \& Dreyer 2013:1). Wat nodig is, is dat die kerk in 'n postmoderne tyd lidmate met 'n verantwoordelike teologie van die huwelik en gesin begelei. Hiervoor is ' $n$ kritiese gesinsetiek ${ }^{3}$ nodig wat as basis kan dien vir die verdere ontwikkeling van toepaslike gesinsbedieningsmodelle en -metodes.

Daarbestaan uiteenlopendemenings van watgesinsbediening behels. Wat dit moeilik maak om 'n werkbare definisie te vind, is die toenemende belangstelling in gesinsbediening sedert die 1990's, met 'n omvangryke aantal organisasies, skrywers, programme, konsultante en kerke wat op die een of ander manier hul benadering as gesinsbediening beskryf (vgl. Clark 1997:13).

Die ontstaan van gesinsbediening kan beskou word teen die agtergrond van (1) die krisis rondom Sondagskool, belydenisklasse en jeugbediening (vgl. Anderson 2009:18, 47; DeVries 2004:24-30, 36-40; Renfro et al. 2009:35; Root 2007:59-61); (2) die ontwikkeling van adolessensie as aparte lewensfase (vgl. Renfro et al. 2009:28-32; Root 2007:5-27, 33); (3) die ontstaan van ouderdom-spesifieke bedieninge (vgl. DeVries 2004:36-40; Renfro et al. 2009:33-34; Root 2007:3031, 38-39), (4) modernisering met die skeiding van ouers en kinders se leefwêrelde (vgl. DeVries 2004:35-43; Root 2007:32) en (5) die krisis in gesinne.

Die 'ontwerp' van adolessensie (Root 2007:28; kyk Renfro et al. 2009:28-33) en die opkoms van ouderdom-spesifieke bedieninge het ' $n$ verlies aan integrasie tussen verskillende geslagte teweeg gebring (Renfro et al. 2009:33, 55-56). Die onbeplande en ongewensde uitkoms hiervan was tweeledig. Eerstens het ouers teruggetree as primêre rolspelers in die geloofsvorming van hul kinders en dit oorgelaat in die hande van kundiges by die kerk (vgl. Anderson 2009:7; Freudenburg \& Lawrence 1998:9194; Renfro et al. 2009:34). Tweedens het gemeentes met ouderdomspesifieke jeugbediening as't ware die naelstring tussen jongmense en volwassenes, asook kinders en ouers geknip, of soos DeVries (2004:43) dit stel, 'n gedeelte (jongmense) van die liggaam van Christus uitgesny. Die resultaat van hierdie tweeledige uitkoms word deur Anderson beskryf:

3.Browning (2007:225) onderskei tussen 'naive familism' en 'critical familism'. Eersgenoemde verwys na die oortuiging dat gesinskohesie belangriker is as ander waardes soos die gelykheid tussen man en vrou, die welstand van kinders en individuele lede van die huisgesin. Laasgenoemde poog om ' $n$ balans te vind tussen gesinskohesie en'n etiek van gelyke agting.

4.Die location-nommer van die Kindle-weergawe word weergegee. 
By the end of the [20th] century, the average self-identified Christian could not name three of the Ten Commandments and did not know who gave the Sermon on the Mount. Regular worship attendance now generally means once or twice a month, and perfect attendance pins are a thing of the past. Worship attendance (let alone adult Sunday school or weekday Bible study) has become optional for dads, if they are in the family picture at all ... Such different results are not due to poor teaching or poor curriculum. They are due to placing all our faith formation eggs in the Sunday school basket, rather than understanding it as having a supportive role to faith formation in the home. (Anderson 2009:48)

Jeugbediening het gefaal, nie vanweë die inhoud en aanbieding daarvan nie, maar vanweë die feit dat die gesin nie meer funksioneer as basis vir geloofsvorming nie (Dean 2010:111). Gesinsbediening het ontstaan teen hierdie agtergrond, as 'n poging om die gesin primêr verantwoordelikheid te hou vir kinders se geloofsvorming (vgl. Garland 1999:370).

'n Werkbare definisie van gesinsbediening behoort die welstand van gesinne sowel as die opbou van gemeentes te bevorder. Die vertrekpunt vir gesinsbediening, in aansluiting by Anderson (2009:23), is dat gemeentes en gesinne in 'n lewende bedieningsvennootskap staan. Gesinsbediening gaan om die toerusting en ondersteuning van pastors, ampsdraers, jeugmentors en alle dienaars in die gemeente, sowel as peetouers, grootouers, ouers en alle ander volwassenes in die huis, buurt en gemeenskap, om hulle evangeliese roeping uit te leef, naamlik om in navolging van Christus te leef en om ander te dien. Dit is 'n bedieing aan gesinne, maar ook ' $n$ bediening deur gesinne.

Gesinsbediening is nie maar net nóg 'n handeling naas die ander kommunikatiewe handelinge in diens van die Evangelie nie. Wat Nel (2001:5065; vgl. Garland 1999:466481 ) in verband met jeugbediening sê, kan ewewel toegepas word op gesinsbediening:

Youth ministry (family ministry) is not about finding an extra place for yet another ministry, but finding a place for youths (families) within every ministry and among people that the ministries are designed to reach and serve - the people to whom God comes by means of the ministries. (Nel 2001:506)

Gesinsbediening gaan daaroor om aan gesinne 'n plek toe te ken as regmatige deelnemers aan die kommunikatiewe handelinge in diens van die Evangelie, nie alleen by die gemeente nie, maar ook by die huis.

\section{'n Vennootskap tussen gemeentes en gesinne}

'n Verweefdheid tussen die bediening van gemeentes en gesinne word reeds in vroeë Christelike gemeentes gevind:

Because the early church met in homes, sacred actions around rituals and common meals in the gathered ecclesia spilled into home life ... Home in such contexts became a little church. (Browning et al. 2000:308)

Deur die geskiedenis van die Christelike kerk was daar kontinuïteit tussen die vergaderde gemeente en die huisgesin

5.Location-nommer van die Kindle weergawe. as kerk. Wanneer huislike rituele en die liturgie van die gemeente ooreenstem, vind wedersydse versterking plaas. Navorsing bevestig die belangrikheid van huislike rituele vir gesinskohesie (vgl. Browning 2007:226). Op hierdie wyse word kinders ook bekendgestel aan die dieper betekenis van kerklike liturgieë. Anderson (2003) sluit hierby aan:

This moment in time encourages the church to reflect further upon its biblical and historical roots and to assess the impact of contemporary experience on the life and work of the church ... This vision of church understands faith formation and mission to the larger world as an outgrowth of this partnership. It offers a foundational model for ministry that has been present since the beginning of the church and yet has been overlooked in our expert and professional-dependant world. This vision of the church recalls what at times has been forgotten: that Christianity is first and foremost a lay movement supported by the trained and committed leadership of clergy and laity alike. (p. 35)

Ook Olson and Leonard (1996:61-62) beskou die gemeente en gesin as twee unieke instellings van God, wie se verantwoordelikhede nie dieselfde is nie, maar wel komplimentêr.

Garland (1999) se studie van meer as 50 gemeentes en 120 gesinne het bevind dat gemeentes 'n raamwerk bied aan gesinne waarbinne hulle geloof gevoed en waardes, soos onvoorwaardelike liefde, toewyding, selfopoffering, viering, vergifnis en genade gevestig word. In 'n toenemend individualistiese samelewing bied gemeentes die ruimte waar egte gemeenskap ervaar kan word:

Church teachings and programs offer parents, spouses and children practical guidance for family living. In the church, people find the support of friends who are journeying through the same stages and transitions of life. The church community also makes possible a wealth of crossgenerational relationships. In the context of the congregation, generations can learn from and care for one another. And in times of crisis, particularly illness, birth and death, churches provide entire families with meaningful and practical care. (Garland 1999:9)

Volgens Sell (1995:14) is beide gesinne en gemeentes instellings van God en behoort daarom in simbiose met mekaar te leef (kyk Barna 2003:106). Só innig beskou Sell die verhouding tussen gemeente en gesin dat gemeentes se missionale integriteit hiervan afhang.

Dit gaan ook om meer as net die gemeente en die gesin. Daar is ' $n$ interaktiewe verhouding tussen vier invloedryke kragte aan die werk: gesin, gemeente, gemeenskap en kultuur (Strommen \& Hardel 2000:18). Hoewel die fokus hier val op die verhouding tussen gesin en gemeente, kan die ander twee hoogs invloedryke kragte nie geïgnoreer word nie (vgl. Browning 2007:226-235; Heitink 2007:20, 351-354; Roberto 2010:11-12; Smith \& Denton 2005:172-181; Thatcher 1999:117-118).

\section{Die ouerhuis as primêre geloofsruimte}

Naas die belangrike plek wat die gesin ingeneem het in die vroeë kerk, toon verskeie studies aan dat die huisgesin, en nie die gemeente nie, dié belangrikste rolspeler is in die 
geloofsvorming van kinders. Waar gesinne en gemeentes se bedieninge verweef word, word beide gemeentes en gesinne in die proses opgebou (kyk Anderson 2009:41; Dean 2010:203; DeVries 2004:59-70; Nel 1998:19-25,109-115, 178; Osmer 2007:202; Strother 2009:140).

Nel (2001) verwys na gesinne as die basiese hermeneutiese lebensraum waarin God kinders en jongmense nader:

Parents are primary mediators in the relationship (or covenant) between God and families, and as such are key in the roles that humans play in the coming of God to children. (pp. 656-666 $)$

In 'n vroeëre werk noem Nel (1998:109-110) ouers die 'primêre bemiddelaars van die heil wat deur die Verbondsmiddelaar bewerk is'. In aansluiting by 'gehegtheidsteorie' (kyk Gottman 2001:18-22; Hendrix 2005:27; Johnson 2003:4-11; Sternberg 1995:463-466) word die belangrikheid ingesien van 'n 'langtermynnabyheidsverhouding' wat deur warmte en sensitiwiteit gekenmerk word en die effek van modellering verhoog.

Modellering verwys daarna dat die lewenstyl van ouers 'n veel groter effek op kinders se geloofsvorming het as woorde. 'Faith is caught more than it is taught' (Anderson 2009:34). Een van die belangrikste beginsels van gesinsbediening skuif hier in die voorgrond, naamlik dat geloof meestal gevorm word deur persoonlike vertrouensverhoudings. Dit is juis binne hierdie persoonlike verhoudings, wanneer ouers hul geloof uitleef in die gebeure van elke dag, dat kinders leer hoe om in navolging van Christus te leef (Nel 1998:111-112). Daar is bevind dat spesifieke gesinspraktyke jongmense help om geloofsgroei te ervaar, soos wanneer gesinne gereeld oor geloof praat, saam huisgodsdiens hou en saam bid, saam aan tafel eet, asook saam barmhartigheidswerk doen (kyk Freudenburg \& Lawrence 1998:167). Dit is nie genoeg dat ouers betrokke gemaak word by die bediening van die gemeente nie (Freudenburg \& Lawrence 1998:191). Hoewel sommige gemeentes ouerbetrokkenheid sien as suksesvolle jeugbediening of selfs gesinsbediening, is dit nodig dat gemeentes betrokke raak by die bediening van ouers by hul huise.

Een van die dwingendste redes waarom gesinsbediening die fokus plaas op die ouerhuis as primêre geloofsruimte, is dat die eerste jare van ' $n$ kind se lewe die fondasie vorm vir alle later ontwikkeling (vgl. Sell 1995:151; Strommen \& Hardel 2000:21). Fowler verwys byvoorbeeld na die eerste 18 maande van 'n kind se lewe as 'n fase waarin die 'pre-images of God' hulle oorsprong het en die eerste basiese raamwerk vir geloof gevorm word, naamlik 'undifferentiated faith':

In the pre-stage called Undifferentiated faith the seeds of trust, courage, hope and love are fused in an undifferentiated way and contend with sensed threats of abandonment, inconsistencies and deprivations in an infant's environment. Though really a pre-stage and largely inaccessible to empirical research of the kind we pursue, the quality of mutuality and the strength of trust, autonomy, hope and courage (or their opposites) developed in this phase underlie (or threaten to undermine) all that comes later in faith development. (Fowler 1981:121)

6.Die location-nommer van die Kindle-weergawe word weergegee.
In 'n volgende ontwikkelingsfase, ouderdom 2-6 jaar, vind daar 'n samesmelting plaas tussen denke en spraak (Fowler 1981:123). Fowler (1981:133) noem dit die fase van 'intuitiveprojective faith', 'n fantasievervulde fase van nabootsing wanneer kinders ten diepste beïnvloed word deur die geloofswoorde, -dade en -verhale van hul primêre versorgers.

Ouers se voorbeeld het 'n bepalende invloed op kinders se diensbaarheid binne die geloofsgemeenskap (vgl. Dean 2010:109). Die mees effektiewe wyse waarop die jeug meer betrokke gemaak kan word by die bedieninge van 'n gemeente, is deur hul ouers meer betrokke te kry. Kinders se godsdienstige verbintenis, verstaan en uitlewing van geloof weerspieël tot 'n hoë mate dié van hul ouers (vgl. Dean 2010, Appendix B). Daarom is die beste projeksie wat gemaak kan word oor hoe jongmense se geloofslewens as volwassenes gaan lyk, hoe hul ouers se geloofslewens daaruit sien.

Dit is derhalwe kommerwekkend dat Strommen en Hardel (2000:13-15; vgl. Nel 1998:109) skryf: 'Only a minority of families today are orientating their children to a life of faith, service, and responsible living.' Dit bevestig die noodsaaklikheid om ouers aan te moedig, te ondersteun en toe te rus vir hierdie taak.

\section{Modelle en metodes van gesinsbediening Verskillende modelle}

DeVries (2004:174-175) maak die nuttige onderskeid tussen 'n gesinsbedieningsmodel en 'n gesinsgebaseerde jeugbedieningsmodel. Hoewel albei erkendebedieningsmodelle is, plaas gesinsbediening die fokus op ouers as primêre geloofsvormers, terwyl jeugbediening wel ouers betrokke kry by die bediening, maar die gemeente primêr verantwoordelik bly daarvoor. Clark (1997:14-19) beskryf drie gesinsbedieningsmodelle, naamlik die terapeutiese, die kerngesin- en gemeente-as-gesin bedieningsmodel. Renfro et al. (2009:37-52) onderskei vier, naamlik die programgedrewe, die gesin-inklusiewe jeugbedieningsmodel, die gesin-gebaseerde en die gesin-geïntegreerde bedieningsmodel. Programgedrewe gesinsbedieningsmodelle, soos die terapeutiese- of beradingsmodel, is volgens die definisie van gesinsbediening wat in hierdie artikel voorgestel word, nie werklik gesinsbediening nie. Dit sou eerder geklassifiseer kon word as pastoraat. Indien die programgedrewe model weggelaat en die gemeente-as-gesin bedieningsmodel wat Clark (1997:14-19) beskryf, hierby gevoeg word, is daar vier duidelike gesinsbedieningsmodelle wat omlyn kan word.

\section{Die gemeente-as-gesin bedieningsmodel}

Twee bydraes tot gesinsbediening kan as gemeente-as-gesin bedieningsmodelle beskryf word, naamlik dié van Sell (1995) en Garland (1999). Sell (1995) beskryf vier bedieningsareas waarop gesinsbediening behoort te fokus, naamlik die koestering van gesinsmatige verhoudings by die kerk (Sell 1995:173-204), huweliksvoorbereiding en -toerusting 
(Sell 1995:209-224), ouertoerusting en -begeleiding (Sell 1995:259), en gespesialiseerde bedieninge (Sell 1995:301). Volgens Sell (1995:173) behoort gemeentes die waardes van huisgesinne, soos aanvaarding, openheid en eerlikheid, te weerspieël. Dit kan veral bereik word deur kleingroepe en groeigroepe. Gesinsmatige verhoudings word aangemoedig deur gemeentelike bedieninge intergeneratief te beplan (Sell 1995:186-204). Verskeie temas rondom ouerbegeleiding verdien aandag, soos modellering, dissipline, kommunikasie en gesinsinteraksie (Sell 1995:259-286). Ouers behoort begelei te word vir die informele sowel as formele Christelike onderrig van hul kinders (Sell 1995:288-297). In ooreenstemming met Deuteronomium 6:4-9 behoort Bybelse waardes verweef te word met die daaglikse lewe van die gesin. Gemeentes behoort terapeutiese hulp te verleen aan gesinne wat uitdagings in die gesig staar (Sell 1995:301-331).

Garland (1999) streef doelbewus daarna om die gemeente as uitgebreide gesin te laat funksioneer, met verskillende individue, gesinne en generasies wat byeen gebring word (kyk Garland 1999:374-375). Gesinsbediening is vir Garland (1999:395) die intensionele strewe om elke aspek van die gemeentelike lewe op só 'n wyse te beïnvloed dat dit die ontwikkeling en transformasie van gesinne aanmoedig, sodat gesinne die liefde van God kan ervaar en uitstraal, en alle lidmate in die gemeente deel kan wees van 'n uitgebreide geloofsgesin. Sodoende sorg gesinne nie alleen vir mekaar binne die gemeente nie, maar is hulle ook missionaal gerig. Die verskillende areas in die gemeente waarop gefokus kan word deur intergeneratiewe gesinsbediening sluit in die erediens, Christelike onderrig, pastoraat, administrasie en ander projekte en bedieninge (Garland 1999:466-481). Die bedoeling van ondersteunings- en onderrigprogramme by gemeentes is om nuwe gesinsverhoudinge binne die geloofsgemeenskap te vestig (Garland 1999:482-514). In haar omvangryke verduideliking van 'n verskeidenheid ondersteuningsgroepe en onderrigprogramme wat gemeentes sou kon aanbied, word gesinne deurlopend betrek en aktiwiteite op intergeneratiewe wyse aangebied. Die onderskeie fokusgroepe waarvoor bedieninge ontwikkel behoort te word, sluit in enkellopendes, aanneemgesinne, homoseksuele persone, gesinne waar ongewenste swangerskappe voorkom, enkelouers (Garland 1999:517530), huwelikspare, persone wat deur egskeiding geraak word, persone wat hertrou (Garland 1999:531-557), asook ouers en kinders (Garland 1999:558-581). Ten slotte val die fokus op gesinne wat deur dood, ongelukke, siektetoestande, gesinsgeweld of seksuele mishandeling geraak word.

\section{Die gesin-inklusiewe jeugbedieningsmodel}

Twee belangrike bydraes tot die gesin-inklusiewe jeugbedieningsmodel is dié van DeVries (2004) en Nel (1998). 'n Gesin-inklusiewe jeugbedieningsmodel fokus daarop om ouderdom-spesifieke bedieninge te ontwikkel, asook aan ouers hulp en bystand te verleen in die geestelike vorming van hul kinders. Die kerngesin is egter nie genoeg nie, aldus DeVries (2004:79), aangesien jongmense 'n uitgebreide geestelike gesin nodig het. Vir sommige jongmense kan die geloofsgesin die enigste Christelike gesin wees wat hulle ken. Die doel van jeugbediening is dus om jongmense te omring met 'n skare geloofsgetuies en hulle op hierdie wyse in te skakel as deel van die liggaam van Christus (DeVries 2004:95). Gesin-inklusiewe bedieninge sluit in gesin-inklusiewe godsdiensonderrig, gebedsgeleenthede, gemeentekampe, ouertoerustingsgeleenthede en 'verstaanjou-tiener'-byeenkomste. Ondersteuning word ook gebied aan nie-tradisionele gesinne en gesinne wat deur krisisse geraak word (DeVries 2004:122-126).

Hoewel jeugbediening met metodes en programme werk, kan geen menslike sisteem genoeg wees om jongmense werklik tot bekering en geloof te lei nie (DeVries 2004:160). Wat gedoen kan word, is om die konteks te skep waarin jongmense in geloof kan groei, waar hulle in ontmoeting kan tree met dié God wat Homself aan ons openbaar. Die beste wat gemeentes kan doen, is om 'God se ontwerp' vir geloofsvorming te volg soos uiteengesit in Deuteronomium 6:4-9 (DeVries 2004:162).

Nel (1998) se inklusiewe gemeentelike benadering gaan van die vertrekpunt uit dat jeugbediening nie ' $n$ aparte bediening van die gemeente uitmaak nie, maar deel is van die totale gemeentebediening (Nel 1998:77). Gemeentes behoort hulself te bekeer van 'n gefragmenteerde ekklesiologie waarin die jeug as 'n aparte groep beskou word. Die kind hoort wesenlik in ag geneem te word ter voorbereiding en uitvoering van die verskillende kommunikatiewe handelinge in diens van die Evangelie (Nel 1998:88-95). Dit is inderdaad bediening aan, met en deur die jeug (Nel 1998:135).

\section{Die gesin-gebaseerde bedieningsmodel}

Anderson (2009:7-8, 69) sien die huisgesin en gesinslewe as die primêre ruimte waar geloof gevorm word. Dit bring 'n korrektief aan die jarelange misverstand dat gemeentes primêr daarvoor verantwoordelik is. Anderson, wat deel uitmaak van Vibrant Faith Ministries, onderskryf die Vibrant Faith Frame waarin ses bedieningsareas, vyf beginsels vir geloofsvorming en vier geloofspraktyke verwoord word (Anderson 2009:34). Die ses bedieningsareas sluit in kinders en jeug, huisgesinne, gemeentes, gemeenskap, kultuur en skepping. Al ses bedieningsareas behoort binne die skopus te val van 'n gemeente se verantwoordelikheid. Vyf geloofsbeginsels wat die basis vorm van gesinsbediening (Anderson 2009:34, 2011:49), word soos volg verwoord:

- Geloof word gevorm binne die raamwerk van persoonlike vertrouensverhoudings, eerder as deur onderrigprogramme en -kurrikulums.

- Daar bestaan'n onmisbare vennootskap tussen diebediening van die gemeente en die bediening van die huisgesin.

- Die huisgesin is 'n gemeente in die kleine.

- Geloof word eerder aangeleef as aangeleer.

- Om kinders en jeug te inspireer en te motiveer, is dit nodig dat hulle omring is deur volwassenes wat 'n navolgingswaardige voorbeeld stel. 
Bogenoemde vyf geloofsbeginsels verstaan die gemeente as wesenlik relasioneel (Anderson 2011:15). Gesinsbediening verbind die meer private lewensruimte van mense, naamlik die huisgesin, met die meer publieke ligging en funksionering van die gemeente. Geloof word nie gevorm deur programme en komitees nie, maar deur interpersoonlike verhoudings en daaglikse ervarings (Anderson 2011:20).

Vier geloofspraktyke wat voorgestel word vir gesinne, is omgeegesprekke, huisgodsdiens, diensbaarheid en rituele en tradisies. Volgens Anderson (2011:15, 74-75) berus die vier geloofspraktyke op die Skrif, kerkgeskiedenis en moderne navorsing. Dié praktyke vind veral plaas tydens die sentrale gemeentelike gebeure, naamlik die erediens, asook die sentrale huislike gebeure, naamlik die etenstafel. Om saam aan die etenstafel te sit behoort een van die belangrikste Christelike rituele vir huisgesinne te wees.

Die spesifieke bedieningsareas waarop Anderson fokus, sluit in Christelike onderrig, prediking en aanbidding, jeugbediening, rentmeesterskap van gemeentelike hulpbronne, kleuterskole, dagsorg, naskoolse programme en administrasie. Wat Christelike onderrig betref, behoort daar ' $n$ verskuiwing plaas te vind na geloofsvorming eerder as onderrig (Anderson 2011:45-49). Die dae van geïsoleerde Sondagskool is verby en die tyd het aangebreek vir intergeneratiewe geloofsvorming. Die fokus behoort eerder daarop te val om kinders te omring deur volwassenes wat egte, beskikbare en toegewyde dissipels van Christus is. In die plek van 'n persoon wat voor staan in 'n klas en kategese gee, vind geloofsvorming plaas in groepsverband met mense van verskillende ouderdomme.

'n Essensiële faset van die Vibrant Faith Ministries-model is 'Milestones Ministry' (Anderson 2011:55-68). Hiermee word bedieninge rondom belangrike rites (mylpale) in mense se lewens ontwikkel. Die motivering hieragter is om geloofsvormende rituele aan betekenisvolle lewensgebeure te koppel. In die eerste plek word belangrike momente vanuit 'n geloofsperspektief geïnterpreteer, maar word huisgesinne ook aangemoedig om hierdie mylpale te gebruik as geleentheid vir omgeegesprekke, diensbaarheid, huisgodsdiens en die skep van rituele en tradisies (die vier geloofspraktyke).

Erediensste speel 'n sentrale rol in die toerusting en voorbereiding van ouers vir hulle opvoedingstaak by die huis (Anderson 2011:75-77). Voorlesing uit die Woord en gebede is hulpbronne wat gesinne toerus vir huisgodsdiens, die liturgie van Sondag help om rituele en tradisies by die huis te skep en met inhoud te vul, die hele erediens en Sondaggebeure is voorbeelde van diens aan God, mekaar en die wêreld, terwyl die atmosfeer en kerklike taal voorbeelde is van omgeegesprekke met mekaar. In Anderson se model vorm gesinsbediening 'n ruitekaart waarvolgens die kommunikatiewe handelinge van die gemeente herbeplan en met nuwe inhoud gevul word, eerder as dat dit uitloop op totaal nuwe bedieningspraktyke.

\section{Die gesin-geïntegreerde bedieningsmodel}

Die enigste voorbeeld van 'n gesin-geïntegreerde bedieningsmodel wat gevind kon word in die literatuur, is dié van Renfro et al. (2009). Ouderdomspesifieke bedieninge is, volgens Renfro (2009:55), die produk van moderne individualisme. 'n Gesin-geintegreerde benadering bied weerstand teen enige bedieninge wat meedoen aan die disintegrasie van gesinne (vgl. Renfro et al. 2009:71-72). Geen voorsiening word gemaak vir ouderdomspesifieke bedieninge nie. Die doel daarvan om gesinne en families in dieselfde erediens te akkommodeer is dat kinders deur modellering kan ervaar wat dit is om God te eer (Renfro et al. 2009:57).

Volgens Renfro et al. (2009:56-61) word eredienste deur die hele gesin bygewoon, met weeklikse kleingroepbyeenkomste waar lidmate in huise ontmoet, ook in gesinsverband. Maandeliks vergader mans van die gemeente met die uitsluitlike doel om ander mans op te lei as geestelike leiers van die gesin. Renfro et al. (2009:60$61,64)$ beskryf die rol van die man spesifiek as geestelike hoof van die huisgesin. Tydens eredienste is dit mans wat voorlees uit die Woord en Nagmaal bedien. Die posisie van mans as gesinshoofde wat verantwoordelik is vir die geestelike versorging van die huisgesin, word geskoei op 'n Bybelse basis (Renfro et al. 2009:67-68, 74). Vroue se Bybelse rolle word gesien as 'complementary helpers for their husbands' (Renfro et al. 2009:75). Hy beskryf gemeentes en gesinne se opvattings wat buite hierdie 'Bybelse standaarde' beweeg as ekklesiologiese pragmatisme, 'n verkeerdelike lees van die Bybel deur kulturele lense, en dat dit kultureel aanvaarde praktyke aan die Heilige Gees toedig (Renfro et al. 2009:77).

In 'n gesin-geïntegreerde bediening vind evangelisasie en dissipelskap in en deur die huisgesin plaas (Renfro et al. 2009:63). Deuteronomium 6 en Psalm 78 dien as voorbeelde om die belangrike rol van ouers te verwoord en te bepaal. Renfro et al. (2009:72) beskryf die verhouding tussen gemeentes en gesinne as '... institutions [that] work together within clearly defined jurisdictional lines to bless each other and to expand Christ's kingdom'.

\section{Kriteria vir evaluering}

Noudat hierdie vier gesinsbedieningsmodelle bespreek is, word die vraag gevra watter van hierdie modelle aan die prakties-teologiese vereistes voldoen wat in 'n vorige artikel (Van Staden \& Dreyer 2013) verwoord is. Met behulp van Browning (et al. 2000, 2003, 20007) en Thatcher (1999) is kriteria ontwikkel waarvolgens bestaande gesinsbedieningsmodelle en -metodes evalueer kan word. Hiervolgens behoort gesinsbediening

- 'n kritiese gesinsetiek as onderbou te hê

- die dinamiese bedieningsvennootskap tussen gemeentes en gesinne te onderskryf 
- teologiese teorieë en gemeentelike programme te ontwikkel wat deur die kommunikatiewe handelinge van die gemeente (1) die huisgesin toerus as belangrike geloofsruimte, (2) 'n gesinspiritualiteit help ontwikkel, (3) beide-ouer-gesinne bevorder en tegelyk alle gesinne ondersteun, (4) die negatiewe gevolge van modernisering en globalisering teëstaan, waarvan die probleem van egskeiding en die toenemende verskynsel van die 'afwesige pa' die belangrikste is, (5) gesinsverhoudings versterk, (6) kontak tussen verskillende generasies bevorder, (7) klem lê op geloofsonderrig en (8) missionaal gerig wees.

\section{Bevinding}

'n Kritiese evaluering van die onderskeie gesinsbedieningsmodelle toon aan dat drie van die vier bedieningsmodelle, naamlik die gemeente-as-gesin bedieningsmodel, die gesin-inklusiewe jeugbedieningsmodel en die gesin-gebaseerde bedieningsmodel grootliks aan die kriteria voldoen. Tussen die genoemde drie bedieningsmodelle is daar merkwaardige ooreenkomste. Die benaderings kan inderdaad, soos Clark (1997:20-23) voorstel, eerder komplimentêr gesien word as uitsluitend. Al drie hierdie bedieningsmodelle kan dus as werkbare opsies beskou word vir gemeentes wat die weg wil volg van gesinsbediening.

Die gesinsgebaseerde bedieningsmodel van Renfro voldoen aan sommige kriteria, soos dat dit die gemeente as geloofsgesin opbou, die huisgesin ag as belangrike geloofsruimte, die probleem van afwesige pa's aanspreek, kontak tussen verskillende generasies aanmoedig en bevorder, nabye verhoudings met God as prioriteit stel, klem lê op Christelike onderrig, asook missionaal ingestel is. Maar Renfro se model ontbreek aan 'n kritiese gesinsetiek. Dit bevorder patriargie en toon geen hermeneutiese sensitiwiteit vir die ontwikkelingsgeskiedenis van die huwelik nie (kyk Van Staden \& Dreyer 2013:3). Een van die belangrikste bronne van kritiek is dat hierdie bedieningsmodel grootliks ontoeganklik is vir kinders wat nie deel is van tradisionele gesinne nie, aangesien geen programme of geleenthede aangebied word buite dié wat vaders fasiliteer nie.

Die gemeente-as-gesin bedieningsmodel is ' $n$ omvattende model wat gesinne beskryf en bedien binne hul sosiologiese, psigologiese, kulturele, ekonomiese en godsdienstige werklikheid (vgl. Garland 1999:19-366). Dit gaan nie alleen om die pastorale begeleiding van gesinne deur die krisisse en uitdagings wat hulle in die gesig staar nie, maar om die verskillende lewensfases van gesinne en gesinslede te verstaan, intimiteit te bevorder, kommunikasie te verbeter, rituele en tradisies te help ontwikkel en die sterk punte van gesinne te ontgin. Om die waarheid te sê, dit gaan primêr nie oor die geluk en vervulling wat gesinne ervaar nie, maar om die missionale identiteit en opdrag van die kerk te vervul. 'n Gesinspiritualiteit in hierdie perspektief gaan daaroor dat gesinne in navolging van Christus leef, beide wat hulle onderlinge verhoudings betref, asook om getuies te wees van God se liefde. Die missionale integriteit van die kerk gaan verlore indien gelowiges nie binne hulle primêre verhoudings saam kan bid, uit God se Woord saam lees en met mekaar oor geloof praat nie (vgl. Garland 1999:388). 'n Moontlike uitdaging, of selfs nadeel, wat 'n gemeente-asgesin bedieningsmodel inhou, is dat dit 'n gekompliseerde, hoogs gespesialiseerde gemeentelike program vereis. 'n Handleiding vir gesinsbediening soos dié van Garland (1999), wat meer as 600 bladsye beslaan, sal waarskynlik die meeste gemeenteleiers afskrik.

Die gesin-inklusiewe jeugbedieningsmodel erken die sterk punte van gesinne en die positiewe effek van goeie ouergewoontes, soos die betrokkenheid van ouers by hulle kinders, die belangrikheid van gesinsmaaltye, die bywoon van eredienste en die daarstel van reëls en grense (vgl. De Vries 2004:60-68). Ongelukkig dui navorsing daarop dat ouers in die meeste gevalle nié hierdie verantwoordelikheid nakom nie (vgl. De Vries 2004:73-80). Derhalwe fokus die gesin-inklusiewe jeugbedieningsmodel op die ontwikkeling van 'n uitgebreide geloofsgesin waarin kinders deel kan wees van 'n 'nuwe gesin', waar hulle minstens een betekenisvolle verhouding opbou met 'n volwasse gelowige wat die waardes van God se koninkryk uitleef (vgl. De Vries 2004:92, 102). In hierdie bedieningsmodel bly die kerk primêr verantwoordelik vir die geloofsonderrig van jongmense en hulle begeleiding tot geloofsvolwassenheid (vgl. De Vries 2004:175). Die nadeel van hierdie bedieningsmodel is dat die huisgesin nie werklik toegerus word as 'n belangrike geloofsruimte nie, 'n gesinspiritualiteit terloops aandag verdien en gesinsverhoudings nie versterk word nie. 'n Positiewe gevolg van hierdie model is veral dat dit kontak tussen verskillende generasies bevorder en missionaal gerig is op diegene wat nie deur gelowige ouers en gesinne ondersteun word nie.

Die gesin-gebaseerde gesinsbedieningsmodel van Anderson (2009) bied die voordeel dat dit 'n relatief eenvoudige, dog teologies verantwoordbare bedieningsplan vir gemeentes voorstel (vgl. Anderson 2009:34). Die kern van hierdie bediening fokus minder op die aktiwiteite van die gemeente as dié van die huisgesin. Van al die modelle bied dit die duidelikste uiteensetting van die 'geloofsleutels' vir huisgesinne, naamlik omgeegesprekke, huisgodsdiens, diensbaarheid en rituele en tradisies (vgl. Anderson 2009:34). Dit is die enigste van die bedieningsmodelle wat eksplisiet melding maak van die ekologiese verantwoordelik wat die kerk het. Hierdie vier geloofsleutels begelei gesinne om diensbaar te wees in die huis, die gemeente, gemeenskap, kultuur en skepping. Gemeentelike bediening word só ontwikkel en gemeentelike leierskap só ingespan dat dit die huisgesin as bedieningsvennoot van die gemeente toerus (vgl. Anderson 1999:41). Wat hierdie bedieningsmodel bied, is prakties-teologiese riglyne en hulpmiddels van hoe om 'n volhoubare gesinspiritualiteit te ontwikkel, wat ook al die aard en samestelling van gesinne is.

Gesinsbediening behoort nie verstaan te word as net nóg ' $n$ bediening tussen ander bedieninge nie (vgl. Anderson 
2009:109; De Vries 2004:115); dit vorm die raamwerk en inhoud van alle gemeentelike aktiwiteite en programme.

\section{Erkenning Mededingende belange}

Die outeur verklaar dat hy geen finansiële of persoonlike verbintenis het met enige party wat hom nadelig in die skryf van hierdie artikel kon beïnvloed nie.

\section{Literatuurverwysings}

Anderson, D.W., 2009, From the great omission to vibrant faith, Vibrant Faith Publishing, Vancoouver.

Anderson, D.W., 2011, Vibrant faith in the congregation, Vibrant Faith Publishing, Vancouver.

Barna, G., 2003, Transforming children in spiritual champions, Regal, Ventura, CA.

Bells, A.O., 1998, The grounding of marriage in the order of creation', in H. Anderson, D.S. Browning, I.S. Evison \& M.S. Van Leeuwen (eds.), The family handbook, pp. 201-203, Westminster John Knox Press, Louisville, KY.

Browning, D.S., 2003, Marriage and modernization. How globalization threatens marriage and what to do about it, William. B. Eerdmans Publishing Company, Grand Rapids, MI.

Browning, D.S., 2007, Equalilty and the family. A fundamental, practical theology of children, mothers, and fathers in modern societies, William B. Eerdmans Publishing Company, Grand Rapids, MI.

Browning, D.S., Miller-McLemore, B.J, Couture, P.D., Lyon, K.B. \& Franklin, R.M (eds.) 2000, From culture wars to common ground: Religion and the American family debate, 2nd edn., Westminster John Knox Press, Louisville, KY.

Carter, W., 1998, 'An alternative household structure (Matthew 19-20)', in H. Anderson, D.S. Browning, I.S. Evison \& M.S. Van Leeuwen (eds.), The family handbook, pp. 224-228, Westminster John Knox Press, Louisville, KY.

Clark, C., 1997, The youth worker's handbook to family ministry: Strategies and practical ideas for reaching your student's families, Zondervan Publishing House, Grand Rapids, MI.

Dean, K., 2010, Almost Christian. What the faith of our teenagers is telling the American church, University Press, Oxford.

DeVries, M., 2004, Family-based youth ministry, 2nd edn., rev. and expanded, Downers Grove, IL.

Fowler, J.W., 1981, Stages of faith. The psychology of human development and the quest for meaning, Harper Collins, New York, NY.

Freudenburg, B. \& Lawrence, R., 1998, The family-friendly church, Group Publishing, Loveland, CO.

Garland, D.R., 1999, Family ministry. A comprehensive guide, InterVarsity Press, Downer's Grove, IL.

Gottman, J.M., 1994, Why marriages succeed or fail... and how you can make yours last, Simon \& Schuster Paperbacks, New York, NY.

Gottman, J.M., 2001, The relationship cure, Three Rivers Press, New York, NY.

Heitink, G., 2007, Een kerk met karakter. Tijd voor heroriëntatie, Uitgeverij Kok, Kampen.
Hendrix, H., 2005, 'The evolution of imago relationship therapy', in H. Hendrix, H. LaKelly, H. Hunt, M.T. Hannah \& W. Luquet (eds.), Imago relationship therapy, pp. 13-34, Jossey-Bass, San Francisco, CA.

Johnson, S.M., 2003, 'Introduction to attachment: a therapist's guide to primary relationships and their renewal', in S.M. Johnson \& V.E. Whiffen (eds.), Attachment processes in couple and family therapy, pp. 3-17, The Guilford Press, New York, NY.

Müller, J., 2002, Gesinne van binne. Vertel die verlede en droom oor die toekoms van jou gesin, Barnabas, Bloemfontein.

Nel, M., 1998, Jeugbediening. 'n Inklusiewe gemeentelike benadering, RGN, Pretoria.

Nel, M., 2001, 'The inclusive congregational approach to youth ministry', in M.H. Senter, W. Black, C. Clark \& M. Nel (eds.), Four views of youth ministry and the church, Zondervan Publishing House, Grand Rapids, MI. (Kindle edn.).

Odendal, F.F \& Gouws, R.H. (reds.), 2005, Handwoordeboek van die Afrikaanse taal, 5 de uitgawe, HAT, Kaapstad.

Olson, R.P. \& Leonard, Jnr., J.H., 1996, A new day for family ministry, Alban Institute, Bethesda, MD.

Osiek, C. \& Balch, D.L., 1997, Families in the New Testament world, Westminster John Knox Press, Louisville, KY.

Osmer, R.R., 2007, 'Family faith formation at the nexus of practical theology and Christian Education', in J. Witte Jr., M.C. Green \& A. Wheeler (eds.), The equalregard family and its friendly critics. Don Browning and the practical theological ethics of family, pp. 202-222, William B. Eerdmans Publishing Company, Grand Rapids, Ml.

Renfro, P., Shields, B., Strother, J. \& Jones T.P. (eds.), 2009, Perspectives on family ministry: 3 views, B\&H Academic, Nashville, TN.

Reuther, R.R., 2001, Christianity and the making of the modern family, SCM Press, London.

Roberto, J., 2010, Faith formation 2020. Designing the future of faith formation, Vibrant Faith Publishing, Vancouver.

Root, A., 2007, Revisiting relational youth ministry. From strategy of influence to a theology of Incarnation, InterVarsity Press, Downers Grove, IL.

Scharfe, E., 2003, 'Stability and change of attachment representations from cradle to grave', in S.M. Johnson \& V.E. Whiffen (eds.), Attachment processes in couple and family therapy, pp. 64-84, The Guilford Press, New York, NY.

Seim, T.K., 1998, 'Ascetic widows in the early church (Luke-Acts and 1 Timothy)', in H. Anderson, D.S. Browning, I.S. Evison \& M.S. van Leeuwen (eds.), The family handbook, pp. 229-232, Westminster John Knox Press, Louisville, KY.

Sell, C.M., 1995, Family Ministry, 2nd edn., Zondervan, Grand Rapids, MI.

Senter, M.H., Black, W., Clark, C. \& Nel, M., 2001, Four views of youth ministry and the church, Zondervan Publishing House, Grand Rapids, MI. (Kindle edn.).

Smith, C. \& Denton, M.L., 2005, Soul searching. The religious and spiritual lives of American teenagers, Oxford University Press, New York, NY.

Sternberg, R.J., 1995, In search of the human mind, Harcourt Brace College Publishers, Orlando, FL.

Strommen, M.P. \& Hardel, R.A. 2000, Passing on the faith: a radical new model for youth and family ministry, Saint Mary's Press, Winona, MN.

Strother, J., 2009, 'Family-equipping ministry', in P. Renfro, B. Shields, J. Strother \& T.P. Jones (eds.), Perspectives on family ministry: 3 views, pp. 140-167, B\&H Academic, Nashville, TN.

Thatcher, A., 1999, Marriage after modernity. Christian marriage in postmodern times, New York University Press, New York, NY.

Van Eck, E., 2007, 'Die huwelik in die eerste-eeuse Mediterreense wêreld (II): Huwelik, egbreuk, egskeiding en hertrou', HTS Teologiese Studies/Theological Studies 63(1), egbreuk, egskeiding en hertrou', HTS Teologiese Studie

Van Staden, J.M. \& Dreyer, Y., 2013, 'Gesinsbediening in 'n postmoderne kerk vanuit Bybels-teologiese perspektiewe', HTS Teologiese Studies/Theological Studies 69(1), Art. \#2049, 7 pages. http://dx.doi.org/10.4102/hts.v69i1.2049 